Retraction

\title{
Retraction: Van Dijk, M.P.; Zhang, M. Urban Water Management Paradigms in Chinese Cities. Sustainability 2019, 11,3001
}

\author{
Meine Pieter van Dijk ${ }^{1, *(D)}$ and Mingshun Zhang $^{2}$ (D) \\ 1 International Institute of Social Studies (ISS) of Erasmus University Rotterdam, \\ 3062 PA Rotterdam, The Netherlands \\ 2 Beijing University of Civil Engineering and Architecture (BUCEA), Beijing 100091, China; \\ zhangmingshun@bucea.edu.cn \\ * Correspondence: mpvandijk@iss.nl
}

check for updates

Citation: van Dijk, M.P.; Zhang, M. Retraction: Van Dijk, M.P.; Zhang, M. Urban Water Management Paradigms in Chinese Cities. Sustainability 2019, 11, 3001. Sustainability 2021, 13, 5992. https://doi.org/10.3390/su13115992

Received: 19 May 2021

Accepted: 25 May 2021

Published: 26 May 2021

Publisher's Note: MDPI stays neutral with regard to jurisdictional claims in published maps and institutional affiliations.

Copyright: (C) 2021 by the authors. Licensee MDPI, Basel, Switzerland. This article is an open access article distributed under the terms and conditions of the Creative Commons Attribution (CC BY) license (https:// creativecommons.org/licenses/by/ $4.0 /)$.
The journal retracts the 28 May 2019 article, cited above [1].

Following publication, concerns were brought to the attention of the journal editorial office regarding an overlap with an unpublished part of a doctoral thesis, subsequent to an investigation that culminated in an Advisory Report of the Academic Integrity Committee (CWI) of the Erasmus University Rotterdam (EUR), dated 28 April 2020.

The report found that Dr van Dijk committed plagiarism and hence violated Paragraph 5.2 (A) of the Code of Conduct (violation of research integrity) and suggested the complaint to be admissible in relation to the author, Dr Van Dijk, and inadmissible in relation to the co-author, Dr Zhang.

The report further stated that "[i]n view of the seriousness and scale of the noncompliance with the Code of Conduct, the Committee recommends that your board take the following into consideration: To send a copy of the report to the Sustainability office accompanied by a request to correct the article to reference Chapters 1 and 2 of the Complainant's work (or dissertation) to be included in \$4.1.1 (Resilient Cities Paradigm, pages 5-7) of the Article, or it should state that §4.1.1 was realised with the use of Chapters 1 and 2 of the Complainant's work (or dissertation)".

The recommendations of CWI were adopted by the Board of EUR in its decision of 19 June 2020. The authors and complainant were provided the opportunity to appeal this decision. Neither party chose to do so.

The journal editorial office gave the authors multiple opportunities over several months to correct the article, but a satisfactory correction was not produced that addressed the EUR's Board decision appropriately. Following further discussion with EUR, the journal took the decision to retract the article on the basis of the plagiarism established by the CWI Advisory Report (as adopted by EUR's Board), and MDPI's policies on authorship disclosure. Due to the ongoing delay in the provision of a satisfactory correction, and the potential for resulting uncertainty to continue indefinitely, the journal editorial office is taking the option of retracting the article. Additionally, in view of the nature of the plagiarized aspect of the article as inherent to the conclusions reported, a partial retraction was deemed inappropriate.

This retraction was approved by the Editor in Chief of the journal.

\section{Reference}

1. Van Dijk, M.P.; Zhang, M. Urban Water Management Paradigms in Chinese Cities. Sustainability 2019, 11, 3001. [CrossRef] 